9. НХМУ (Національний художній музей України). ДАФ. Ф. 28. Оп. 1. Од. зб. 19, арк. 1

10. НХМУ (Національний художній музей України). ДАФ. Ф. 28. Оп. 1. Од. зб. 24, арк. 1.

11. НХМУ (Національний художній музей України). ДАФ. Ф. 28. Оп. 1. Од. зб. 42, арк. 1.

12. Павельчук I. А. Мотив с деревом в краєвидах Абрама Маневича із збірки Національно художнього музею. Мистецтвознавчі записки : зб. наук. праць. Київ : Міленіум, 2014. Вип. 26. С. 249-259.

13. Павельчук І. А. Традиції формального образотворення Японії у практиці фрранцузьких постімпресіоністів 1880 1890-х років (до проблем асиміляції постімпресіонізму в мистецтві України XX-XXI століть). Вісник Харківської державної академії дизайну і мистецтв. Харків : ХДАДМ, 2017. № 4. С. 57-65.

14. Поспелов Г. Русский сезаннизм начала XX века. Поль Сезанн и русский авангард начала XX века : каталог / ред. А. Г. Костеневич. Санкт-Петербург : Славия, 1998. С. 158-166.

15. Сезанн П. Переписка. Воспоминания современников/ сост., вступ. ст., примеч. Н. В. Яворской ; пер. Е. Р. Классон, Л. Д. Липман. Москва : Искусство, 1972. 368 с.

16. Тугендхольд Я. Итоги сезона (Письмо из Парижа). Аполлон. 1911. № 6. С. 69-70.

17. Cezannism. InCoRM. 2010. URL: http://www.incorm.eu/styles.html (дата звернення : 24.12.2018).

18. Mourey G. Abraham Manievitch. Exposition Manievitch : Catalogue des Peintures de Abraham Manievitch / Galerie Durand-Ruel. Paris, 1913. $16 \mathrm{p}$.

19. Novotny F. Cézanne. Vienna : Phaidon, 1937. 20 p. : 126 plates.

Стаття надійшла до редакції 10.05.2019 р.

UDC 785.7:788.1/.4

Paliichuk Iryna

Ph.D. in History of Arts, assistant professor of Ukrainian music and folk instrumental art of

V. Stefanyk Prycarpath National University

ORCID: 0000-0001-9641-5240

paliichuk@i.ua

\title{
GENRE AND STYLISTIC TRENDS IN THE DEVELOPMENT OF MINIATURES FOR BRASS INSTRUMENTS IN THE UKRAINIAN MUSICAL CULTURE OF 30-70s OF XX CENTURY
}

The purpose of the offered article is determination of the characteristic tendency of progress of genre of miniature trends for brass wind instruments in the Ukrainian musical culture of 30-70-th of XX of century. Methodology of the research is based on the usage of methods: textual and source studies - while working with different genre sources of the select issue, analytical and typological - for the detection of immanent features of certain examples of analysable genre and their association in corresponding typology groups. The scientific novelty of work lies in the introduction to scientific turnover of the certain note writing material firstly analysed and generalization of leading genre-stylish tendencies of development of the mentioned genre outlined chronologically. Conclusions. On the basis of analysis of the number of corresponding works there are exposed their genre-stylish features, and also the basic stages of evolution of the mentioned genre are determined: formation (1930-50), stabilization (1960-70) and modification (1980-90).

Key words: genre, miniature, the brass winds, Ukrainian music, performance on the brass wind instruments.

Палійчук Ірина Степанівна, кандидат мистецтвознавства, доцент, доцент кафредри музичної україністики та народно-інструментального мистецтва ДВНЗ «Прикарпатський національний університет імені Василя Стефраника»

Жанрово-стильові тенденції розвитку мініатюри для мідних духових інструментів в українській музичній культурі $30-70-x$ років XX століття

Мета пропонованої статті полягає у визначенні характерних тенденцій розвитку жанру мініатюри для мідних духових інструментів в українській музичній культурі 30-70-х років XX століття. Методологія дослідження ґрунтується на використанні методів: текстологічного та джерелознавчого - при опрацюванні різножанрових джерел з обраної проблеми, аналітичного та типологічного - при виявленні іманентних особливостей конкретних прикладів аналізованого жанру та їх об'єднання у відповідні типологічні групи. Наукова новизна роботи полягає у введенні у науковий обіг певного нотографічного матеріалу, проаналізованого вперше та узагальненні провідних жанрово-стильових тенденцій розвитку названого жанру окресленого хронологічного відтинку. Висновки. На основі аналізу низки відповідних творів розкрито їх жанрово-стильові особливості, а також визначено основні етапи еволюції названого жанру: формування (1930-50), стабілізації (1960-70) та модиффікації (1980-90).

Ключові слова: жанр, мініатюра, мідні духові інструменти, українська музика, виконавство на мідних духових інструментах.

Палийчук Ирина Степановна, кандидат искусствоведения, доцент, доцент кафредры музыкальной украинистики и народно-инструментального искусства ГВУЗ «Прикарпатский национальный университет имени Василия Стефаника»

Жанрово-стилевые тенденции развития миниатюры для медных духовых инструментов в украинской музыкальной культуре 30-70-х годов XX века

Цель предлагаемой статьи заключается в определении характерных тенденций развития жанра миниатюры для медных духовых инструментов в украинской музыкальной культуре 30-70-х годов XX века. Методология исследования основана на использовании методов: текстологического и источниковедческого - при обработке разножанровых источников по выбранной проблеме, аналитического и типологического - при выявлении имманентных особенностей конкретных примеров рассматриваемого жанра и их объединения в соответствующие типологические группы. Научная новизна работы заключается во введении в научный оборот определенного нотографичного материала, проанализированного впервые и обобщении ведущих жанрово-стилевых тенденций развития названного жанра очерченного хронологического отрезка. Выводы. На основе анализа ряда соответствующих произведений раскрыто их жанрово-стилевые особенности, а также определены основные этапы эволюции названного жанра: формирование (1930-50), стабилизации (1960-70) и модификации (1980-90). инструментах.

Ключевые слова: жанр, миниатюра, медные духовые инструменты, украинская музыка, исполнительство на духовых 
Actuality of the research. A wind instrument art is the important constituent of the Ukrainian instrumental culture, that on the modern stage is characterized considerable achievements both in industry of performing on the adopted instruments and in composer's work. The wide spectrum of economic and expression feasibilities of wind instruments makes them the unchanging participants of heterogeneous orchestras and ensembles. The representatives of different generations of Ukrainian composer's school appealed to timbre-semantic potential of the adopted instruments - L. Revutsky, B. Lyatoshinsky, M. Sylvansky, M. Dremlyuga, Y. Shchurovsky, V. Homoliak, O. Znosko-Borovsky, J. and L. Koloduby, E. Stankovich, A. Kostin, D. Kitsenko, L. Duma, S. Zaghitko, L. Yurina et al. Consequently, work of the Ukrainian authors for wind instruments is presented by various genres - from solo plays, sonatas, various ensembles to the scale concerto-symphonic forms.

Analysis of researches and publications. Its research is one of the priority directions of modern musicology that is developing actively. The row of dissertation works, devoted to Ukrainian composers' work for a pipe (V. Posvalyuk, B. Mocourad, O. Varyanko, P. Vakalyuk, Li Siabin), trombone (F. Kryzhanivsky, O. Fedorkov, G. Martsenyuk, Ya. Sadivsky), genre of concert for brass wind instruments (I. Paliichuk) has appeared lately.

Very useful information in the light of the marked range of problems is given by editions from a cycle the "Creative portraits of the Ukrainian composers», devoted to the work of B. Lyatoshynsky [11], L. Kolodub [2], G. Tsitsalyuk [9], A. Shtogarenko [1] and others. Sections «Chamber instrumental ensembles» [3] and «Music for chamber instrumental ensemble» by Kalenichenko A. [4] from the multivolume academic «History of Ukrainian music» turned out to be basic for the given research.

Despite of the number of scientific studies about work for wind instruments, a miniature for the brass wind instruments of the Ukrainian authors of 30-70-th of XX centuries, which are the stages of forming and crystallization of the adopted genre remains understudied.

Purpose of the offered article is to determine characteristic trends of development of miniature for brass wind instruments in Ukrainian music of the outlined time period.

Exposition of basic material. A miniature plays an important role in education of professional performers. In the initial and middle links of musical education it serves as artistic material, on which the certain aspects of future musicians' performing mastery - expression of playing, ability to «sing» on an instrument, development of feeling of phrase and internal hearing.

The work on the pieces enables students to perform the works with more difficult texture, content and form, such as a sonata, rhapsody, concert, suite and others. Concerto implementation of miniatures needs the artist's mature musical thinking and playing mastery.

This genre has played a great role in the history of Ukrainian creativity for brass wind instruments, since the miniature in the first half of the twentieth century was the basis of the original solo repertoire for these instruments [10, p. 33]. His lion's share was translation for the mentioned instruments of vocal compositions or works written for other musical instruments. The authors of these transcriptions were themselves for the most part, the performers on wind instruments. In particular, trumpeters V. Yablonsky, L. Mogilevsky, P. Ryazantsev, trombonist O. Dooberserdov and others.

Thus, the original solo repertoire for copper wind instruments of the designated chronological section is represented by Scherzo O. Chishka (1935), Polonese fantasy by V. Ivanovsky (1941), Scherzo by L. Mogilevsky, Nokturn and Scherzo by R. Svirsky (1952) for a trumpet; «Melody» for horns accompanied by piano B. Lyatoshinsky (1951); «Scherzo» for three trombones by O. Znosko-Borovsky (1938) and Two plays on Moldavian themes for trombone and piano I. Vilensky (1955). The stylistic principles of these works determine the peculiarities of Ukrainian and European music of the first half of the 20-th century, in particular new modern trends and trends, which are manifested in the complication of the chordal vertical, the absence of the tone centre, etc.

It should also be noted that the 1930s-50s were a rather difficult period for Ukrainian music, marked by artificial planting "above» the "necessary» artistic processes associated with narrow and dogmatic interpretation of the principles of programming, nationality, ideology, simplification of the problem of with folklore. The artificial isolation from world-wide modern experience was further enhanced [8, p. 10-11]. However, during this chronological period, the professional experience of composers was accumulated, in particular in the field of wind creativity, both orchestral and solo, without which it would not have been possible to evolve the national musical art of the next timepiece.

In many works of a particular period of time composers resorted to Ukrainian themes and into national sources of music from other peoples of the former USSR. In the works for brass wind instruments of the 1950s, Ukrainian themes are clearly manifested in the «Melodies» for horns accompanied by the piano B. Lyatoshynsky written on the basis of the music to the film «Taras Shevchenko».

In the score for this film, the composer skilfully used folk pieces, in particular, the melody of spring songs (episode "The Night on Ivan Kupala») and the lengthy song "Oh, I'll go over meadow» (episode of meeting with my sister) [7, p. 140-141]. Actually, the latter is into nationally similar to the musical and thematic material «Melodies», written in a simple three-part form. The theme of the first section (f-moll) is characterized by smoothness, enriched with triolum rhythmic figures, oversized lengths, which give musical ex- 
pression of expressiveness. The second time the theme is carried out in another tonal «illumination» - it sounds for a second second lower (es-moll), in addition, enriched with chromatizes.

At the same time appeared «Two plays on Moldovan themes» for trombone or phagote I. Vilensky. This is a kind of cyclical work, consisting of a lyric miniature "The Song» and a mobile "March». The first play (f-moll) (simple two-part form) is based on the cantabile theme, which is characterized by a rich rhythmic pattern: it contains dashed rhythm, triolian motifs, ornamentation, characteristic of Moldovan musical culture. It seems to be a function of lyrical admission to the next, larger-scale play, based on several images. They organically embody the form of rondo. The «march» begins with the theme of the active character (f-moll), which serves as a refrain, and is initially carried out by the piano, later - a sizing instrument. In general, miniatures for brass wind instruments created by Ukrainian authors during the 1930s-1950s are associated with the assimilation of classical-romantic ambushes of the genre, creativity that is more or less in the stream of traditions. These, in particular, are plays by L. Mogilevsky, O. Chishko, R. Svirsky and other authors.

L. Mogilevsky's name was included in the history of brass art as a famous artist, a professor at the Odessa Conservatory, as well as the author of a series of works for the trumpet, transcriptions for the mentioned instrument of sonatas and concerts by V.-A. Mozart, L. Beethoven, R. Strauss.

"Scherzo» for a piano tube, written in the traditions of Western romanticism stands out between the compositions of this author. The work is based on the opposition of the active, scherzo nature of the themes, with lyrical-passionate, which organically embodies the complex three-part form.

The same style features are typical for «Scherzo» by O. Chishko (Des-dur) and «Scherzo» by R. Svirsky (g-moll). The works are very interesting in the structural respect: in general, they contain features of a large-scale three-part composition, the extreme sections of which are written in a complex three-part form. Thus, the analyzed compositions are characterized by a wealth of themes and images.

Consequently, the genre of miniatures for brass wind instruments in the works of Ukrainian authors during the 1930s-50s developed mainly in the course of the passive inheritance of language-style traditions laid down in the nineteenth century and meaningful in the 1930s as «classical», "folk». And therefore are suitable for imitation. However, the analyzed works are valuable in terms of disclosing the technical and expressive capabilities of these instruments and serve as the basis for the further evolution of this genre in the following chronological sections.

1960-1970s in the history of the development of Ukrainian musical art are characterized as a period of renewal of all its sites. It is at this time that the «iron curtain» between Soviet and foreign culture is somewhat more transparent than in previous decades, which contributed to the convergence and mutual enrichment of different national traditions and innovative searches.

Well-known works include B. Bartok, A. Berg, P. Gindemita, I. Stravinsky, A. Schoenberg, $O$. Messian and others, which certainly influenced the renewal of Ukrainian musical art: in this chronological period there are such style trends as «New folk wave», neoclassicism, neo-romanticism, etc. Less direct was the influence on the art of ideological factors that could impede the formation of new trends [10, p. 39].

The expansion of international contacts has also become an impetus for the development of brass art in Ukraine in the fields of composing and performing arts. In the 1960s, the repertoire for the pipe greatly complemented the versatile works of the famous performer, teacher and composer (the composition of G. Maiboroda) M. Berdiyev. He is the author of miniatures, sketches, sonatas, three concerts for a pipe accompanied by piano, ensemble compositions, by G.-F. Handel, V.-A. Mozart, L. Beethoven, V. Kosenko, L. Revutsky translated for trumpet.

The value of these opuses testifies to their inclusion in the programs of many competitions of performers on brass wind instruments. Such works for M. Berdiyev's trumpet as Elegy (1965), Humorresca (1965), Poem (1974) and Scherzo (1974) confidently entered the pedagogical and concert repertoire of modern musicians

«Poem» is an expanded composition of lyric and dramatic nature, the structure of which defines a complex three-part form. The topic of the pipe is characterized by jumps at wide intervals; dash rhythm, syncopes and triples give her an excitedly-passionate character. It is amplified by the piano party, which in the first section of the composition (a simple two-part form of type $A+A_{1}$ ) is a turn-like austenitic harmonic background.

The basis of «Scherzo» is a graceful, playful image. The trumpet party is characterized by ease and is saturated with swirling cheek-shaped passages. Her background is the transparent chord detail of the piano party, which supports the melodic-thematic line of soloist in certain semantic moments.

The multi-genre works for wind instruments make up a significant part of the creative work of L. Kolodub. Great popularity among young musicians is «Humorous Crater» for the band accompanied by an orchestra or piano L. Kolodub (1971). This is one of the few works of Ukrainian authors, in which the soloist acts as an instrument. Tuba is interpreted by the composer in a rather unusual role for her - in the dance genre, widespread in Ukraine. Cadillac is characterized by a lively character. This, obviously, predetermined the name of the analyzed composition, because it is difficult for tub to perform such a genre of music.

The spectacular miniature for a piano accompaniment is «Dance» for the trumpet and piano by O. Kanershtein. Like L. Kolodub, the author appeals to Ukrainian folk dances. The melodic-intonation vocabulary of $\mathrm{O}$. Kanershtein's play resembles «Kozachok» - a massive round dance that arose in antiquity. Like 
a national analogue, a work (simple three-part form) begins with the introduction of an invocative character. The main part of «Dance» is vivid and cheerful. The thematic line of the pipe thanks to the staccato is lightweight, rich in melisma's.

The brightly expressed national colour distinguishes miniatures for a trumpet escorted by the piano «On a bank at a pond» (Es-dur) and «Lullaby» (g-moll) of L. Kolodub.

Note that one of the immanent features of composer style $L$. Kolodub is a strong rooting into folk soil. Thus, the first of the analyzed plays is the processing of folk songs. The work is written in cross-sectional form, where each «stanza» is based on another musical-thematic material and does not contain repetitions.

The miniature "Lullaby» for a chorus accompanied by a piano L. Kolodub is based on a quote by the author of the Ukrainian folk song "Gray kitty, little kitty». The structure of this play defines a simple three-part form. It should be noted the versatility and pictorial features of the piano party, which successfully reproduces the genre specificity of the lullaby and directly named song. In general, the musical and thematic material is characterized by incitement, lyrical character, sustained in the dynamic nuance.

«Elegy» for a trumpet, or trombone, or bassoon, or baritone L. Kolodub (1971), belongs to the lyrical plan of compositions for wind instruments of the specified chronological period «Elegy» for horn and chamber orchestra (piano) G. Tsitsalyuk (1972), «Song Without Words» for a trumpet accompanied by a piano A. Shtogarenko.

The interest in wind instruments is also an inherent feature of G. Tsitsalyuk's creativity. He is the author of a number of works for flute, horns, trumpets, in which the composer demonstrated a fairly good understanding of the colour of sound of a particular instrument.

«Elegy» for horn and chamber orchestra (piano) G. Tsitsalyuk (b-moll) (1971) is an example of the author's concept of musical elegy in the twentieth century (O. Kurchanov). In a work written in a simple threepart form, the composer manifoldly reveals the expressive possibilities of horns. So, in the first section (15time cycle from two sentences for 6 and 9 cycles) the instrument is interpreted by the author in a lyrical role. The melodic-thematic line is characterized by long, longitudinal duration, smooth gradual movement, unprincipled deployment of the themes, causing associations with sad reflection.

"A Song Without Words» for a trumpet accompanied by a piano A. Shtogarenko appeals to lyrical images of the Romantic era. The analyzed play (a simple three-part form) causes allusion to F. Mendelssohn's «Without Words» (in particular, Op. 30 No. 6, Op. 62 No. 5 entitled «The Song of the Venetian Gondolier») and "Barcarolos» by J. Offenbach of Opera "Tale of Hoffman». Significant signs of this genre are in the size of $6 / 8$, a peculiar rhythmic drawing accompanied by a piano party, which creates a feeling of swaying the boat on the water. The melodic-intonation line of the trumpet is distinguished by tenderness and chastity.

Therefore, the scientific novelty of the proposed work is to carry out the analytical characteristics of miniatures involving brass wind instruments B. Lyatoshinsky, I. Vilensky, L. Mogilevsky, O. Chishko, R. Svirsky, M. Berdiyev, L. Kolodub, O. Kanershtein, G. Tsitsalyuk, A. Shtogarenko, on the basis of which the characteristic tendencies of the genre of this genre are determined in Ukrainian music in a definite period of time.

Conclusions. Consequently, the evolution of the miniature genre for brass wind instruments of the twentieth century in Ukraine took place in the context of the development of national musical art and under the influence of Western European musical culture. This is manifested, in particular, in the cultivation of the genres of Scherzo, Nocturne, Polonaise, Elegy, Poem, Songs Without Words and others, which demonstrates a somewhat scholarly version of European romanticism.

During the second half of the twentieth century, this genre was marked by a significant evolutionary path, which is divided into the following time spans:

1930s-50s - the stage of formation of the genre: appearance of the first original miniatures for brass wind instruments, dominated by the lyrical and romantic direction, which serves as a sign of national mentality (L. Mogilevsky, O. Chishko, R. Svirsky), as well. There is a reliance on folk song and dance creativity (B. Lyatoshinsky, I. Vilensky).

1960-70s - the stage of stabilization of the genre: the miniature is one of the leading genres of creativity for brass wind instruments of Ukrainian authors. The stylistic model for these compositions often serves neo-romanticism, presented in the most «moderate» features (M. Berdiyev, G. Tsitsalyuk, A. Shtogarenko). Assimilating the stylistic features of everyday music, composers specify the situation - dramatic, ethnoethnographic, etc. The genre is recognized in intonation sense and the ways of the thematic development.

A number of analysed thumbnails, in which there is a strong connection with the genres of folk music (L. Kolodub, O. Kanershtein), in particular the quoting of a particular folk model (L. Kolodub), is marked by the influence of the «new folk wave», which expressively reflects their national specificity.

In the 1980s and 90s, the work «Dance over the abyss» for four trumpets and the symphony orchestra O. Kostin, «Markato» for the trumpet and piano O. Krasotov, «Deo Volentum» for the trumpet and string quartet A. Tomlionova appeared, "Swing» for trombone and marimba O. Shchetynsky and many others, which demand further investigation of the evolution of the genre of miniatures for brass wind instruments. 


\section{References}

1. Borovik, N.(1961). A. Y. Shtogarenko : an essay on the life and work. Kyiv [in Ukrainian].

2. Zagaykevich, M. (1973). Levko Kolodub: creative portraits of Ukrainian composers. Kyiv : Musical Ukraine [in Ukrainian].

3. Kalenichenko, A. P. (1992). Chamber-instrumental ensembles. G. Skrypnyk (Eds.), History of Ukrainian music: in six volumes. (Vols. 4), (265-286). Kyiv : Scientific Opinion [in Ukrainian].

4. Kalenichenko, A. P. (2004). Music for the chamber and instrumental ensemble. G. Skrypnyk (Eds.), History of Ukrainian music: in six volumes. (Vols. 5), (295-310). Kyiv [in Ukrainian].

5. Kotlyarevskaya, O. I. (2005). Levko Nikolayevich Kolodub - the artist of the present. Levko Kolodub: pages of creativity (articles, research, memories). Scientific herald NMAU by P. I. Tchaikovsky. (Issue 50) (pp. 7-13). Kyiv [in Ukrainian].

6. Kurchanova, A. V. (2005). Elegy music, genre modeling experience (based on works by Russian and Ukrainian composers of the nineteenth and twentieth centuries). Extended abstract of candidate's thesis. Kharkiv [in Ukrainian].

7. Litvinova, O. U. (2004). Music to movies. G. Skrypnyk (Eds.), History of Ukrainian music: in six volumes. (Vols. 5), (336310). Kyiv [in Ukrainian]. Ukrainian]

8. Muha, A. I. (2004). Introduction. G. Skrypnyk (Eds.), History of Ukrainian music: in six volumes. (Vols. 5), (7-18). Kyiv [in

9. Ocheretovskaya, N. (1987). Gregory Tsitsalyuk. Kyiv [in Ukrainian].

10. Paliichuk, I. S. (2007). The Ukrainian concert for brass wind instruments (1950-2000): the formation, strengthening and modifications of the genre. Candidate's thesis. Kyiv [in Ukrainian].

11. Samokhvalov, V. (1981). Boris Lyatoshinsky: creative portraits of Ukrainian composers. Kyiv: Muz. Ukraine [in Ukrainian]

12. Slupsky, V. (2004). Spirit instruments in the work of Levko Nikolayevich Kolodub. Scientific herald NMAU by P. I. Tchaikovsky. (Issue 83) (pp. 108-113). Kyiv [in Ukrainian].

\section{תimepamypa}

1. Боровик М. А. Я. Штогаренко: нарис про життя і творчість К., 1961. 66 с.

2. Загайкевич М. Левко Колодуб: творчі портрети українських композиторів. К. : Музична Україна, 1973. 60 с.

3. Калениченко А. П. Камерно-інструментальні ансамблі // Історія української музики : в шести томах / гол. редкол. Г. Скрипник. К. : Наукова думка, 1992. Т. 4. С. 265-286.

4. Калениченко А. П. Музика для камерно-інструментального ансамблю // Історія української музики : в шести томах / гол. редкол. Г. Скрипник. К., 2004. Т. 5. С. 295-310.

5. Котляревська О. І. Левко Миколайович Колодуб - митець сучасності // Левко Колодуб: сторінки творчості (статті, дослідження, спогади). Науковий вісник НМАУ ім. П. І. Чайковського : зб. наук. праць. К., 2005. Вип. 50. С. 7-13.

6. Курчанова О. В. Елегія в музиці: досвід жанрового моделювання (на матеріалі творів російських та українських композиторів XIX-XX ст.) : авторедр. дис. ... канд. мист. Харків. 2005. 17 с.

7. Литвинова О. У. Музика до кінофрільмів // Історія української музики : в шести томах / гол. редкол. Г. Скрипник. К., 2004. T. 5. C. $336-348$

8. Муха А. І. Вступ // Історія української музики. К., 2004. Т. 5. С. 7-18.

9. Очеретовська Н. Григорій Цицалюк. К. : Муз. Україна, 1987. 35 с.

10. Палійчук І. С. Український концерт для мідних духових інструментів (1950-2000): фоормування, усталення, модифікації жанру : дис. ... канд. мист. : 17.00.03 / ІМФЕ ім. М. Т. Рильського НАН України. Київ, 2007. 217 с.

11. Самохвалов В. Борис Лятошинский : творчі портрети українських композиторів. К. : Муз. Україна, 1981. 52 с.

12. Слупський В. Духові інструменти у творчості Левка Миколайовича Колодуба // Науковий вісник НМАУ ім. П. І. Чайковського. К., 2004. Вип. 83. С. 108-113. 